\title{
Prenatally diagnosed partial trisomy $3 q$ case with an omphalocele and less severe phenotype
}

\author{
Prenatal tanisı konulmuş, omfalosel ve hafif fenotipik anormalliklere \\ sahip kismi trizomi $3 q$ olgusu
}

\author{
Deniz Cemgil Arıkan¹, Ayhan Coşkun¹, Ilker Arıkan², Gürkan Kıran¹, Gülay Ceylaner ${ }^{3}$ \\ ' Department of Obstetrics and Gynecology, Kahramanmaraş Sütçü Imam University, Kahramanmaraş, Turkey \\ ${ }^{2}$ Department of Obstetrics and Gynecology, Zonguldak Karaelmas University, Zonguldak, Turkey \\ ${ }^{3}$ Intergen Genetics Center, Ankara, Turkey
}

\section{Abstract}

Trisomy $3 q$ is a very rarely reported chromosomal disorder. Duplication of part of the long arm of human chromosome 3 causes a distinct and severe syndrome that leads to multiple congenital abnormalities. A 27 year-old pregnant woman was admitted to our clinic at 17 weeks of gestation. Prenatal sonography identified a fetus with an omphalocele that contained the liver and bowel, mild ventriculomegaly and polyhydramnios. Amniocentesis revealed the karyotype of 46, XY, der (3) (3qter $\rightarrow 3 q 21:: 3$ pter $\rightarrow 3 q$ ter). The pregnancy was subsequently terminated. Postnatally, the proband showed midfacial hypoplasia, micrognathia, hypoplastic 12th ribs, omphalocele and prominent heels. We reported this partial trisomy $3 q$ case because he had less marked malformations compared to other reported cases and also different features such as an omphalocele and hypoplastic 12th rib which have not been described previously in an isolated Trisomy $3 \mathrm{q}$ case with this karyotype.

(J Turkish-German Gynecol Assoc 2010; 11: 228-32)

Key words: Partial Trisomy 3q, omphalocele, amniocentesis

Received: 16 December, 2009

Accepted: 11 February, 2010

\section{Introduction}

Trisomy $3 \mathrm{q}$ is a very rarely reported chromosomal disorder. The majority of cases have involved duplication of the segment 3q21-qter and, in most cases, these duplications are the result of unbalanced segregations of balanced parental translocation involving chromosome 3 (1).

Duplication of part of the long arm of human chromosome 3 causes a distinct and severe syndrome that leads to multiple congenital abnormalities. Some of the malformations include congenital heart defects (septal defects), renal malformations (polycystic kidneys or dysplasia), ocular malformations (strabismus, nystagmus, cataract, corneal opacities, colobomas of the iris, and anophthalmia), facial malformations (hypertrichosis, hypertelorism, anteverted nostrils, long philtrum, maxillary prognathism, downturned corners of the mouth, cleft palate, micrognathia) and limb anomalies (hypoplasia of the phalanges, camptodactyly and clinodactyly), malformed

\section{Özet}

Trizomi 3q nadir görülen bir kromozom anomalisidir. İnsan 3. kromozomunun uzun kolunun bir kısmının duplikasyonu multipl kongenital anormalliklerle birlikte olan farklı ve ciddi bir sendroma yol açar. Yirmi-yedi yaşındaki gebe kadın mevcut gebeliğinin 17. haftasında polikliniğimize başvurdu. Fetusta yapılan prenatal ultrasonografide, karaciğer ve barsak içeren omfalosel, hafif ventrikülomegali ve polihidramnios tespit edildi. Yapılan amniyosentez sonucunda karyotip 46, XY, der (3) (3qter $\rightarrow 3 q 21:: 3 p t e r \rightarrow 3 q$ ter) geldi. Ardından tıbbi terminasyon uyguland. Terminasyon sonrası fetusta; midfasiyal hipoplazi, mikrognati, hipoplastik 12. kosta, omfalosel ve çıkıntılı topuklar tespit edildi. Biz bu olguyu, daha önce yayınlanmış izole Trizomi 3q olgularına göre daha hafif malformasyonlar içermesi ve ayrıca omfalosel ve hipoplastik 12. kosta gibi onlarda bulunmayan ek anomalilere sahip olması nedeniyle yayınladık.

(J Turkish-German Gynecol Assoc 2010; 11: 228-32)

Anahtar kelimeler: Kısmi Trizomi 3q, omfalosel, amniyosentez

Geliş Tarihi: 16 Aralık 2009

Kabul Tarihi: 11 Şubat 2010

auricles, short/webbed neck, seizures and brain malformations (2).

Here we report a prenatally diagnosed partial Trisomy $3 q$ (46, XY, der(3) (3qter $\rightarrow 3 q 21:: 3 p t e r \rightarrow 3 q$ ter) karyotype) case with an omphalocele (containing liver and bowel) and a less severe phenotype than the previously reported cases with such a large duplicated segment.

\section{Case Report}

A 27 year-old G3P1A1C0 pregnant woman was admitted to the Kahramanmaras Sutcu Imam University Obstetrics Outpatient Clinic for pregnancy follow-up. She had a first trimester pregnancy loss and pregnancy termination history due to diaphragmatic hernia, short extremities and DandyWalker malformation. The parents were relatives (first degree cousins). There was no positive family history. Prenatal sonography at 17 weeks revealed a $31 \times 21 \mathrm{~mm}$ sized ompha- 
locele protruding out of the abdominal wall on the right side of the umbilical cord that contained the liver and bowel (Figure 1), mild ventriculomegaly and polyhydramnios. The couple was counseled and amniocentesis was performed after their written informed consent form had been obtained. Amniocytes were cultured in three independent culture flasks and then harvested. Chromosome analysis was performed at 550 band level and 46,XY,der(3)(3qter $\rightarrow 3 q 21:: 3 p t e r \rightarrow 3 q$ ter), partial trisomy $3 \mathrm{q}$ was detected. This trisomy includes the segment between q21 band to q terminal. The couple decided to terminate the pregnancy which was carried out at 21 weeks gestation. Postmortem examination revealed midfacial hypoplasia, micrognathia, hypoplastic $12^{\text {th }}$ ribs, omphalocele and prominent heels (Figure 2). As the couple did not permit autopsy, prenatal ultrasound findings were confirmed with magnetic resonance imaging. Parental chromosome analysis was performed and maternal pericentric inversion of chromosome 3 (46, XX, inv (3) (p26q21)) was detected, while the father had normal (46, XY) karyotype.

Research ethics approval was obtained from the Ethics Committee of Kahramanmaras Sutcu Imam University and signed informed consent was obtained from the patient.

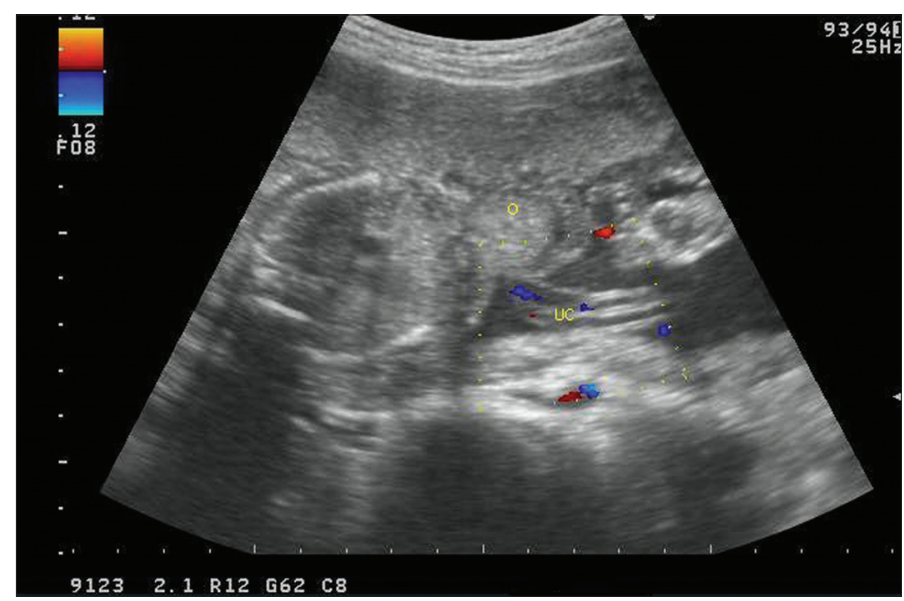

Figure 1. Ultrasonographic view of omphalocele (o: omphalocele, uc: umbilical cord)

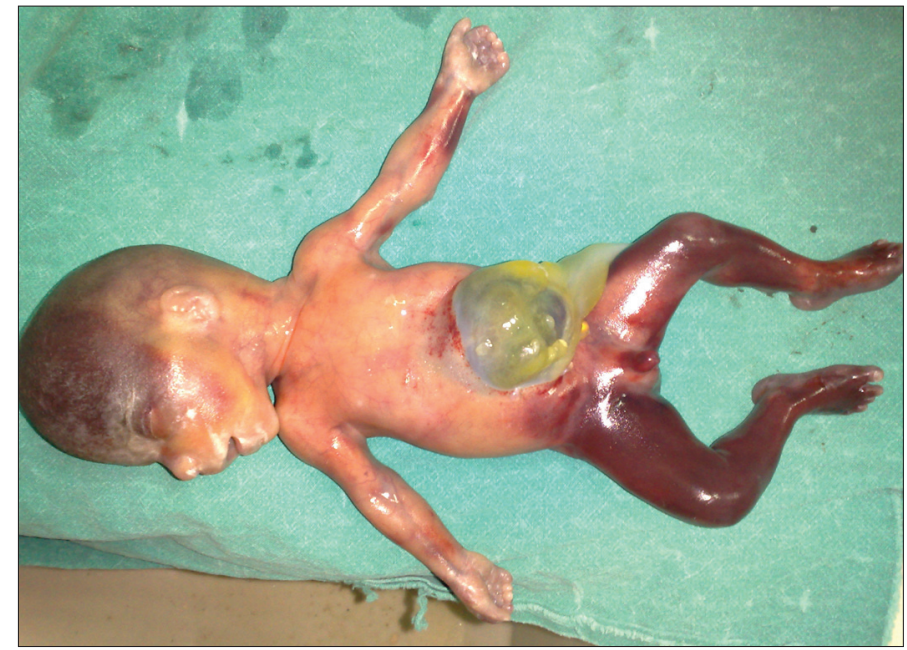

Figure 2. Anterior view of baby

\section{Discussion}

In the literature, to our knowledge, 94 patients with duplication of $3 \mathrm{q}$ have been reported. However, pure duplications are rare because most of the reported patients appear to carry unbalanced translocations. Also, recently mostly cases with more distal duplications-either single abnormalities or associated with a deletion of another chromosomal segment-have been described. Our case had 46, XY, der (3) (3qter $\rightarrow 3$ q21::3pter $\rightarrow 3$ qter) karyotype and we could only find 8 familial and 6 de novo cases with the same duplicated segment in the literature. The dysmorphic findings reported in these cases, and in partial Trisomy $3 \mathrm{q}$ cases with duplication of different segments, show significant differences from each other, as given in Table 1 (3-23). Compared to these cases, our patient manifested a less severe clinical picture, with some unusual characteristic features such as midfacial hypoplasia, hypoplastic $12^{\text {th }}$ rib and prominent heels (Table 1 ). The case we present is a new example of familial cases.

Steinbach et al. described the most common abnormal features in these cases, such as statomotoric retardation, shortened life span, and multiple congenital anomalies (MCA) including abnormal head configuration, hypertrichosis, hypertelorism, ocular anomalies, anteverted nostrils, long philtrum, maxillary prognathia, down-turned corners of the mouth, highly arched or cleft plate, micrognathia, malformed auricles, short, webbed neck, clinodactyly, simian crease, talipes, and congenital heart disease (4). As shown in Table 1, micrognathia, short neck and eye anomalies were the most common findings among reported cases. Thoracic abnormality (absent ribs) was reported only by Steinbach et al (4) while our case had a hypoplastic 12th rib. An omphalocele is a herniation of bowel, liver and other abdominal viscera into a membranous sac with the umbilical cord at its apex. The prevalence of omphalocele varies considerably, ranging from 0.8 to 3.9 per 10,000 births (23). Abnormal karyotypes have been reported in 10 to $40 \%$ (combined mean rate of $12 \%$ ) of neonates with omphaloceles. Trisomy 18 and 13 are the most common associating chromosomal anomalies, followed in frequency by trisomy $21,45, \mathrm{X}$ (Turner syndrome) and triploidy (24). Usually, abnormal karyotype incidence increases when the liver is intracorporeal (25). Chen et al. (3) reported a case with duplication of $3 \mathrm{q} 21 \rightarrow$ qter and deletion of $11 \mathrm{q} 23 \rightarrow$ qter resulting from an unbalanced segregation of a maternal $t(3 ; 11)$ reciprocal translocation. At prenatal sonographic examination they demonstrated an omphalocele containing the liver (3). Yatsenko et al. (23) reported a case with karyotype of 46,XY,der (4)t(3;4)(q27.3;q32.3)mat, resulting in trisomy for 3q27.3 $\rightarrow$ qter and monosomy for 4q32.3 $\rightarrow$ qter. Their case had an omphalocele that contained part of the left hepatic lobe, stomach, and transverse colon. They also searched the literature to identify previously reported cases of partial trisomy $3 \mathrm{q}$ associated with omphalocele, and found that 26 of 93 cases presented with an omphalocele (23). In all of them, the area of duplication includes the region $3 \mathrm{q} 27.3 \rightarrow$ qter. Yatsenko et al also attempted to specify which chromosomal region is responsible for omphalocele and searched previously reported 40 patients with monosomy of 4q. They found that none of them had omphalocele. As a result, they suggested that a dosage-sensitive locus on 
Table 1. Comparison of clinical phenotype of our case with cases in the literature

\begin{tabular}{|c|c|c|}
\hline & Literature & Our case \\
\hline Head and neck & $\begin{array}{ll}\text { - } & \text { Cleft lip, plate (Blumberg, 1980; Pires, 2005) } \\
\text { - } & \text { Broad and flat nasal bridge (Blumberg, 1980; Zafra de la Rosa, 2005; } \\
\text { Gamerdinger, 2006; Gimelli, 2007) } \\
\text { - } \quad \text { Anteverted nostrils (Chiyo,1976; Fear,1979; Blumberg, 1980; Ismail, 1991; } \\
\text { Gimelli, 2007) } \\
\text { - } \quad \text { Malformed ears (Blumberg, 1980; Ismail, 1991; de Azevedo Moreira, } \\
\text { 2005; Carreira, 2009) } \\
\text { - } \quad \text { Downturned corners of the mouth and thin lips (Ismail, 1991; Zafra } \\
\text { de la Rosa, 2005; Gamerdinger, 2006; Grossmann, 2009) } \\
\text { - } \quad \text { Micrognathia (Chiyo,1976; Fear,1979; Kondo,1979; Ismail,1991; Pires, } \\
\text { 2005; Zafra de la Rosa, 2005) } \\
\text { - Short neck (Chiyo,1976; Fear,1979; Kondo,1979; Ismail,1991; de } \\
\text { - } \quad \text { Cyzevedo Moreira, 2005; Zafra de la Rosa, 2005; Gimelli, 2007) } \\
\text { - } \quad \text { Wide nasal bridge (Zafra de la Rosa, 2005; Grossmann, 2009) } \\
\text { Prominent philtrum (Zafra de la Rosa, 2005; Gamerdinger, 2006; } \\
\text { Grossmann, 2009) } \\
\text { Prominent forehead (Gamerdinger, 2006) }\end{array}$ & $\begin{array}{l}\text { Midfacial hypoplasia } \\
\text { Micrognathia }\end{array}$ \\
\hline Eye & $\begin{array}{ll}\text { - } & \text { Coloboma of iris (Fryns, 1984) } \\
\text { - } & \text { Cataract (Mulcahy, 1979; Gustashaw, 1985) } \\
\text { - } & \text { Microphthalmia (Fear, 1979; Steinbach, 1981; Qureshi, 1994; de } \\
& \text { Azevedo Moreira, 2005) } \\
\text { - } & \text { Corneal opacities and other eye malformations (Blumberg, 1980; } \\
& \text { Qureshi, 1994; de Azevedo Moreira, 2005) } \\
\text { - } & \text { Congenital glaucoma (Kondo,1979; Blumberg, 1980) } \\
\text { - } & \text { Coloboma of optic nerve (Ayral, 1984) } \\
\text { - } & \text { Hypertelorism (Ismail, 1991; Zafra de la Rosa, 2005; Gamerdinger, 2006; } \\
& \text { Grossmann, 2009) } \\
\text { - } & \text { Epicanthic folds (Zafra de la Rosa, 2005; Grossmann, 2009) }\end{array}$ & Could't evaluated \\
\hline Thorax & - $\quad$ Absent ribs (Steinbach, 1981) & Hypoplastic 12th rib \\
\hline Skeletal system & $\begin{array}{ll}\text { - } & \text { Thoracic hemivertebrae (Steinbach, 1981) } \\
\text { - } & \text { Narrow pelvis (Steinbach, 1981) } \\
\text { - } & \text { Dislocated elbow (Steinbach, 1981; Zafra de la Rosa, 2005) } \\
\text { - } & \text { Dislocated wrist (Steinbach, 1981) } \\
\text { - } & \text { Dislocated phalanx (Steinbach, 1981) }\end{array}$ & Normal X-rays \\
\hline Extremities & $\begin{array}{ll}\text { - } & \text { Clenched hands (Steinbach, 1981) } \\
\text { - } & \text { Abnormal dermatoglyphics (Steinbach, 1981) } \\
\text { - } & \text { Bifid thumb (Mulcahy, 1979; Steinbach, 1981) } \\
\text { - } & \text { Polydactyly (Fryns, 1979) } \\
\text { - } & \text { Syndactyly (Kondo, 1979; Zafra de la Rosa, 2005) } \\
\text { - } & \text { Fifth-finger clinodactyly (Chiyo, 1976; Fear, 1979; Blumberg, 1980; Zafra } \\
& \text { de la Rosa, 2005; Gimelli, 2007) } \\
\text { - } & \text { Short limbs (Blumberg, 1980; Gimelli, 2007) }\end{array}$ & Prominent heels \\
\hline
\end{tabular}




\begin{tabular}{|c|c|c|}
\hline & $\begin{array}{l}\text { - Abnormal foot position (de Azevedo Moreira, 2005; Zafra de la Rosa, } \\
\text { 2005; Carreira, 2009) } \\
\text { - } \quad \text { Brachydactyly (Grossmann, 2009) } \\
\text { - } \quad \text { Congenital hip dysplasia (Gamerdinger, 2006) }\end{array}$ & \\
\hline $\begin{array}{l}\text { Internal organ } \\
\text { anomalies }\end{array}$ & $\begin{array}{ll}\text { - } & \text { Cardiac anomalies (Chiyo, 1976; Fear, 1979; Steinbach, 1981; Pires, 2005; } \\
& \text { Zafra de la Rosa, 2005) } \\
\text { - } & \text { Polycystic kidney (de Azevedo Moreira, 2005) } \\
\text { - } & \text { Renal anomalies (Blumberg, 1980) } \\
\text { - } & \text { Renal cystic dysplasia (Blumberg, 1980) } \\
\text { - } & \text { Renal cortical cysts (Chiyo, 1976; Fear, 1979) } \\
\text { - } & \text { Unilateral renal agenesis (Blumberg, 1980) } \\
\text { - } & \text { Renal calcification (Ismail, 1991) } \\
\text { - } & \text { Adrenal neuroblastoma (Qureshi, 1994) } \\
\text { - } & \text { Malrotation (Blumberg, 1980) } \\
\text { - } & \text { Lung hypoplasia (Blumberg, 1980; Qureshi, 1994) } \\
\text { - } & \text { Omphalocele (Mulcahy, 1979; Chen, 1996; Yatsenko, 2003; Park, 2008) }\end{array}$ & $\begin{array}{l}\text { Omphalocele (containing } \\
\text { liver and bowel) }\end{array}$ \\
\hline $\begin{array}{l}\text { Central nervous } \\
\text { system }\end{array}$ & $\begin{array}{ll}\text { - } & \text { Dandy- Walker malformation (Chiyo, 1976; de Azevedo Moreira, 2005) } \\
\text { - } & \text { Cerebellar hypoplasia (Steinbach, 1979) } \\
\text { - } & \text { Arhinencephaly (Steinbach, 1979) } \\
\text { - } & \text { Hypoplasia of corpus callosum (Steinbach, 1979) } \\
\text { - } & \text { Microcephally (Blumberg, 1980) } \\
\text { - } & \text { Spina bifida (de Azevedo Moreira, 2005; Gimelli, 2007) }\end{array}$ & Ventriculomegaly \\
\hline Genital system & $\begin{array}{ll}\text { - } & \text { Hypospadias (Fryns, 1984) } \\
\text { - } & \text { Bicornuate uterus (Chiyo, 1979; Blumberg, 1980) } \\
\text { - } & \text { Streak ovaries (Blumberg, 1980) } \\
\text { - } & \text { Duplication of the vagina and cervix (Blumberg, 1980) } \\
\text { - } & \text { Ambiguous genitalia (Gimelli, 2007) }\end{array}$ & \\
\hline Anal anomalies & $\begin{array}{ll} & \text { Anteriorly placed anus (Fryns, 1979) } \\
\text { - } & \text { Anal stenosis (Gustashaw, 1985) }\end{array}$ & \\
\hline
\end{tabular}

the distal 3q could be responsible from an omphalocele (23). Our case also has an omphalocele and no other chromosomal component other than a duplicated $3 q$ segment.

In partial Trisomy $3 q$ cases the abnormal genotypes are usually the result of parental abnormalities of chromosome 3 . Reciprocal translocation is the most frequent parental chromosome anomaly. In our case, parental chromosome analysis demonstrated a maternal pericentric inversion of chromosome 3 (46, XX, inv (3) (p26q21)). Fear et al (8) demonstrated 5 (83\%) maternal and 1 (17\%) paternal structural anomalies in parents of 6 Trisomy $3 q$ cases. Yatsenko et al. (23) demonstrated malsegregation of a parental balanced chromosomal rearrangement in $41(64 \%)$ of 64 families, and the remaining (36\%) were de novo. In cases with omphalocele, inheritance was maternal in $6(\% 75)$ and paternal in $2(25 \%)$ of 8 families. Pericentric inversions, unlike other balanced chromosomal variations, may cause deletion and duplication in conceptuses due to unbalanced cross-over in meiosis. These deletions or duplications may be either of a size detectable under the microscope as in our case, or be very small and may escape observation. Thus, if unbalanced chromosomal alterations have not been detected by conventional cytogenetic analyses in such cases, the recently developed array-CGH method should be recommended for scanning submicroscopic deletions and duplications.

In conclusion, we reported this partial trisomy $3 q$ case because he had less marked malformations compared to other reported cases and also different features such as an omphalocele and hypoplastic 12th rib, which have not been described previously in an isolated Trisomy $3 \mathrm{q}$ case with $46, \mathrm{XY}$, der (3) (3qter $\rightarrow 3 q 21:: 3$ pter $\rightarrow 3 q$ ter) karyotype. For detection of etiology and determination of the risk in subsequent pregnancies, parental chromosomal analysis is mandatory in cases with this kind of structural chromosomal alt.

\section{Conflict of interest}

No conflict of interest is declared by authors. 


\section{References}

1. Chen CP. Chromosomal abnormalities associated with omphalocele. Taiwan J Obstet Gynecol 2007; 46: 1-8.

2. Stallings R, Vaughn D, Hall K, Joyce C, Ryan F, Barton D, Geraghty M. Mosaicism for trisomy $3 q$ arising from an unbalanced, de novo $t$ (3; 1 5). J Med Genet 1997; 34: 512-24.

3. Chen CP, Liu FF, Jan SW, Chen CP, Lan CC. Partial duplication of 3q and distal deletion of $11 \mathrm{q}$ in a stillbirth with an omphalocele containing the liver, short limbs, and intrauterine growth retardation. J Med Genet 1996; 33: 615-7.

4. Steinbach P, Adkins WN Jr, Caspar H, Dumars KW, Gebauer J, Gilbert EF, et al. The dup(3q) syndrome: report of eight cases and review of the literature. Am J Med Genet 1981; 10: 159-77.

5. Ayral D, Raudrant D, Charleux JP, Noel B. Duplication of the long arm of chromosome 3 (dup 3q) in a newborn infant whose the father is carrier of pericentric inversion of chromosome 9. Pediatrie 1984; 39: 681-90.

6. Blumberg B, Moore R, Mohandas T. Partial 3q trisomy due to an unbalanced 3/10 translocation. Am J Med Genet 1980; 7: 335-9.

7. Chiyo H, Kuroki Y, Matsui I, Niitsu N, Nakogome Y. A case of partial trisomy 3q. J Med Genet 1976;13: 525-8.

8. Fear C, Briggs A. Familial partial trisomy of the long arm of chromosome 3 (3q). Arch Dis Child 1979; 54: 135-8.

9. Fryns JP, van Eygen M, Logghe N, Van den Berghe H. Partial trisomy for the long arm of chromosome 3 [3(q21 to qter)+] in a newborn with minor physical stigmata. Hum Genet 1978; 40: 333-9.

10. Gustashaw K, Crowe C, Dickerman L, Golden W, Johnson W. $3 q 21 \rightarrow q 29$ in a male due to a de novo duplication inversion. Am J Med Genet 1985; 37: A95.

11. Ismail SR, Kousseff BG, Kotb SM, Kholeif SF. Duplication 3q (q21 $\rightarrow$ qter) without limb anomalies. Am J Med Genet 1991; 38: 518-22.

12. Kondo I, Hirano T, Hamaguchi H, Ohta Y, Haibara S, Nakai H, et al. A case of trisomy 3q21 leads to qter syndrome. Hum Genet 1979; 46: 141-7.

13. Mulcahy MT, Pemberton PJ, Sprague P. Trisomy 3q: two clinically similar but cytogenetically different cases. Ann Genet 1979; 22: 217-20.

14. Qureshi F, Jacques SM, Johnson MP, Reichler A, Evans MI. Microscopic neuroblastoma in a fetus with a de novo unbalanced translocation 3;10. Am J Med Genet 1994; 53: 24-8.

15. de Azevedo Moreira LM, Neri FB, de Quadros Uzeda S, de Carvalho AF, Santana GC, Souza FR, et al. Multiple congenital malformations including severe eye anomalies and abnormal cerebellar development with Dandy-Walker malformation in a girl with partial trisomy 3q. Ophthalmic Genet 2005; 26: 37-43.

16. Pires A, Ramos L, Venâncio M, Rei AI, Castedo S, Saraiva J. Prenatal foetal diagnosis of partial trisomy $3 \mathrm{q}$ and monosomy $13 \mathrm{p}$ due to a maternal balanced rearrangement. Prenat Diagn 2005; 25: 292-5.

17. Park JK, Lee JI, Jo HC, Shin JK, Lee SA, Lee JH, et al. Efficacy of array comparative genomic hybridization in a fetus with an inherited apparently balanced translocation: A case report. J Obstet Gynaecol Res 2008; 34: 653-7.

18. Grossmann V, Müller D, Müller W, Fresser F, Erdel M, Janecke AR, et al. "Essentially" pure trisomy 3q27 --> qter: further delineation of the partial trisomy 3q phenotype. Am J Med Genet A 2009; 149A: 2522-6.

19. Zafra de la Rosa G, Venegas-Vega CA, Monroy N, Contreras-Bucio G, Friedrich U, Houman M, et al. Trisomy 3q25.1-qter and monosomy 8p23.1-pter in a patient: cytogenetic and molecular analysis with delineation of the phenotype. Am J Med Genet A 2005; 136: 259-64.

20. Carreira IM, Melo JB, Rodrigues C, Backx L, Vermeesch J, Weise A, et al. Molecular cytogenetic characterisation of a mosaic add(12) (p13.3) with an inv dup(3) (q26.31 --> qter) detected in an autistic boy. Mol Cytogenet 2009; 2: 16.

21. Gamerdinger U, Bosse K, Eggermann T, Kalscheuer V, Schwanitz G, Engels H. First report of a partial trisomy 3q12-q23 de novo--FISH breakpoint determination and phenotypic characterization. Eur J Med Genet 2006; 49: 225-34.

22. Gimelli G, Giorda R, Beri S, Gimelli S, Zuffardi O. A large analphoid invdup (3) (q22.3qter) marker chromosome characterized by array-CGH in a child with malformations, mental retardation, ambiguous genitalia and Blaschko's lines. Eur J Med Genet 2007; 50: 264-73.

23. Yatsenko SA, Mendoza-Londono R, Belmont JW, Schaffer LG. Omphalocele in trisomy 3q: further delineation of phenotype.Clin Genet 2003; 64: 404-13.

24. Baird PA, MacDonald EC. An epidemiologic study of congenital malformations of the anterior abdominal wall in more than half a million consecutive live births. Am J Hum Genet 1981; 33: 470-8.

25. Hidaka N, Tsukimori K, Hojo S, Fujita Y, Yumoto Y, Masumoto K, et al. Correlation between the presence of liver herniation and perinatal outcome in prenatally diagnosed fetal omphalocele. J Perinat Med 2009; 37: 66-71. 